\title{
Digital Game-Based Learning for Remedial Mathematics Students: A New Teaching and Learning Approach in Malaysia
}

\author{
${ }^{1}$ Sayed Yusoff Syed Hussain, ${ }^{2}$ Wee Hoe Tan and ${ }^{3}$ Muhammad Zaffwan Idris \\ ${ }^{13}$ Faculty of Art, Computing \& Creative Industry, Sultan Idris Education University, \\ 35900 Tanjong Malim, Perak, Malaysia \\ ${ }^{2}$ Education Research Laboratory, Sultan Idris Education University, \\ 35900 Tanjong Malim, Perak, Malaysia \\ ${ }^{1}$ farihin02@yahoo.com \\ Abstract
}

\begin{abstract}
This paper presents a game-based learning study in Malaysia in which a game has been designed for remedial Mathematics students at primary school level, Mathenatics is a core subject taught in all primary schools in Malaysia. However, for students who are recognized as weak in Mathematics, teachers use remedial modules supplied by the Ministry of Education in teaching and learning activities. A research study has been initiated to propose digital game-based learning for the remedial students, aimingag enhance the effectiveness of the modules. A prototype game is designed to be playable on tablet computers. The game contains lessons under the title of Whole Numbers: Addition in Year Two syllabus. This paper reveals the concepts and rationale behtha the study and the game design. The research plan is also included to justify the ecological validity of the study.
\end{abstract}

Keywords: Game-based learning, remedial Game design

\section{Introduction}

The use of multimedia for teaching and learning could be in various forms, but how video [1] and digital games could be integrated into existing education system remains as an important issue and trend in the academia [2-4]. Digital games which are commonly regarded as a fom of entertainment, has been proposed as an effective tool for engaging students in learning activities [5]. The number of research studies related to digital games have been increasing since mid-2000, covering a wide range of disciplines, such as arithmetic [6], computer science [7], mathematics [8-9] and so on. Many studies have found out that digital game-based learning (DGBL) is an effective way to enhance students' learning motivation and performance [10-12]. In particular, [13] indiated that the alignment between game design and instructional design has a great impaet on the effectiveness of students' learning. Therefore, considering how to design digital games which can fit the needs of learning activities has become the keystone of DGBL [14].

Meanwhile, if the aim of DGBL practice is to increase the achievement of remedial students, then it is important to consider how to help the students to improve their learning performance using games. In Malaysia, remedial students are those who face learning difficulties in specific skills, hold negative views towards learning, possess behaviors which could affect learning, and lack of both self-confidence and positive attitudes towards learning [15]. Scholars in the field of educational research have suggested that teachers should pay more attention to individual differences when 
teaching or providing remedial instruction to students with low achievement [16-17]. In fact, DGBL could be one of the learning approaches that can be used to remedy the shortcomings of traditional teacher-centred instruction, which has been commonly accused for ignoring the needs of students with low achievement [5].

This paper presents a DGBL approach, which is a form of new teaching and learning activity that has not been practiced in the formal education system in Malaysia. In this approach, a bespoke digital game was designed and developed for remedial students to replace module commonly used by school teachers. Students's performance would be assessed at the end of the learning session.

\section{Literature Review}

DGBL is a form of student-centred learning that uses digital games for educational purposes [18]. It has been found that games evoke in players' experience of flow and positive emotions [19]. A number of studies have found that the application of video games can enhance learning motivation, and learning attitudes [3], and [7]. After personally engaging in various electronic games, Ko [201 discovered that many of the most inspired electronic toys contain important learning principles. In addition to entertaining students, games can help students to develop thinking skills [21].

Educational research related to game-based learning in mathematics has revealed a lot potential. According to Betz [22] and Moreno, [23] çopiputer games can be used as a tool to facilitate effective mathematics leaning and increase the motivation of students. For example, Piaget considered playing as an important matter for the intellectual development of children [24]. There are also quite a number of empirical studies [25] which suggest that games can be an effective tool to engage students in mathematics or arithmetic, specifically in enticlung instruction on conceptual understanding and problem solving.

From the literature review, many research by DBGL in mathematics has been done [8-9,14, 26-32]. Table 1 slown the research by DGBL in Mathematics from scholars in around the world.

\section{Table 1. Research by DGBL in Mathematics}

\begin{tabular}{|l|l|l|}
\hline Scholar & Year & Research area \\
\hline Swearingen & 2011 & Achievement \\
\hline Karafili and Stana & 2012 & Learning \\
\hline Kebritchi Hirumi and Bai & 2010 & Achievement and motivation \\
\hline Ke & 2006 & Performance and mathematics behavior \\
\hline Lee & 2008 & Achievement \\
\hline Chen, Liao, Cheng, Yeh and Chan & 2012 & Perception and motivation \\
\hline Ntourlia Gouscos and Meimaris & 2010 & Behavior and achievement \\
\hline Vandermaas-peeler, Ferretti \& Loving & 2012 & Achievement and collaborative \\
\hline Gallegos and Flores & 2010 & Game development \\
\hline Hung, Huang, and Hwang & 2014 & $\begin{array}{l}\text { self- efficacy, motivation, anxiety, and } \\
\text { achievements }\end{array}$ \\
\hline
\end{tabular}


In many countries around the world, the performance in mathematics of students is generally low, as revealed by the Program for International Student Assessment (PISA). According to the Organisation for Economic Co-operation and Development (OECD), [33], most countries have more than $40 \%$ of students aged 15 years old are struggling at Level 1 or below in mathematics, that means they do not have the basic knowledge to succeed in the upper level in school. Thus, it is important to develop techniques that can help students to improve their performance across different types of learning and as sessment settings.

According Felicia, [34] digital games have some implicit educational benefits. They allow spaces to develop cognitive and motor skills, which in turn help to improve students' mathematics skills. According to a Cabinet Report or Laporan Kabinet, [35] paragraph 33.1 stresses that those who are weak in certain skill areas should be given remedial teaching regularly. Adhering to this statement, implementing remedial teaching in the classroom is an important aspect of teaching, that must-be noted by teachers [36]. In Malaysia, remedial programed in mathematics is being run under a project called Literacy and Numeracy Screening (LINUS) which is managed by the Curriculum Development Division, under the Ministry or Education since 2010. In this project, every pupil in Year 1, 2 and 3 will go through the screening typice a year [37].

\section{DGBL Methodology}

\subsection{Design of DGBL}

A DGBL model is designed specifically for the development of a remedial mathematics game, titled 1 Minit Ujian Matematik. This model is known as IDDTI model, which is a derivative form of the classic water all software development model [38]. It consists of five phases: idea, design, development, testing and mplementation, as shown in Figure 1. Each phase has a sequential working arrangement, in which the description of every phase in the IDDTI model is shown in ext section. All of the phases are hierarchically related to each other. The model is designed and developed based on the premise that subject matter experts (SME) and game design expert (GDE) should collaborate to produce quality games for use in education [39]

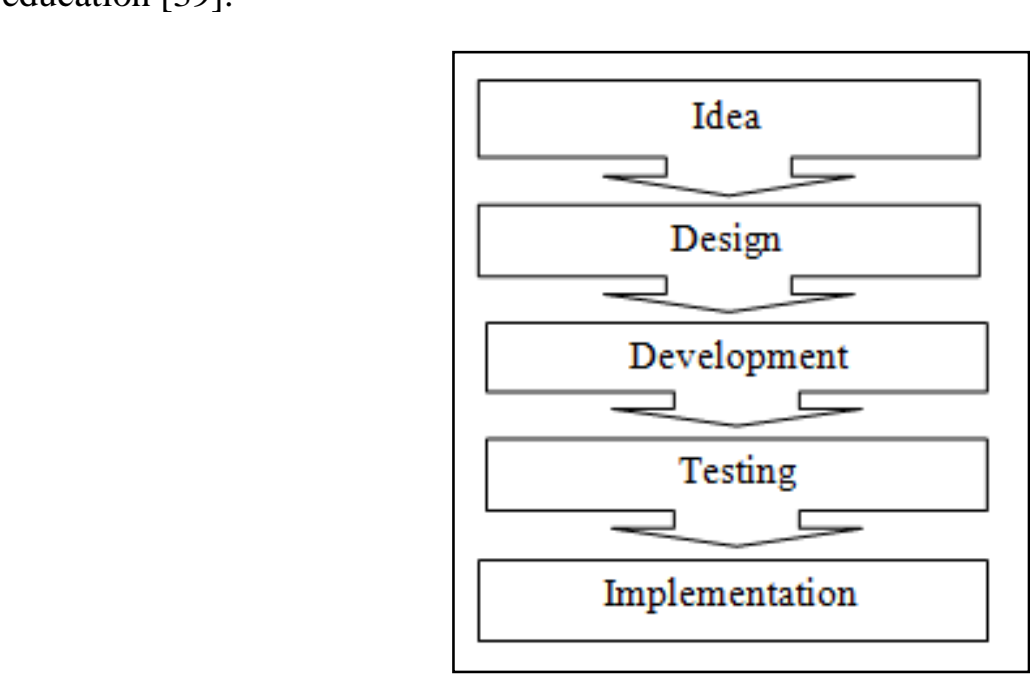

Figure 1. IDDTI Model 
3.1.1. IDDTI model: In the Idea phase, game ideas and learning ideas can be nurtured in three stages, namely idea generation, idea expansion and idea refinement, as shown in Figure 2. Generating ideas is the first step of the collaboration between SME and GDE. In this stage, the SME and GDE meet or talk to each other to determine a number of things, including the subject matter, syllabus, topics to be covered, skills to be included, game design, game mechanics, game characters and in-game challenges. Once these ideas are created, they will discuss to develop these ideas in the idea expansion stage. Next, in the idea refinement stage, decisions made and specific design directions which have been selected will be refined in order to achieve unity in variety and congruence in game design [40]. All the finalized ideas are taken to the Design phase of the IDDTI model.

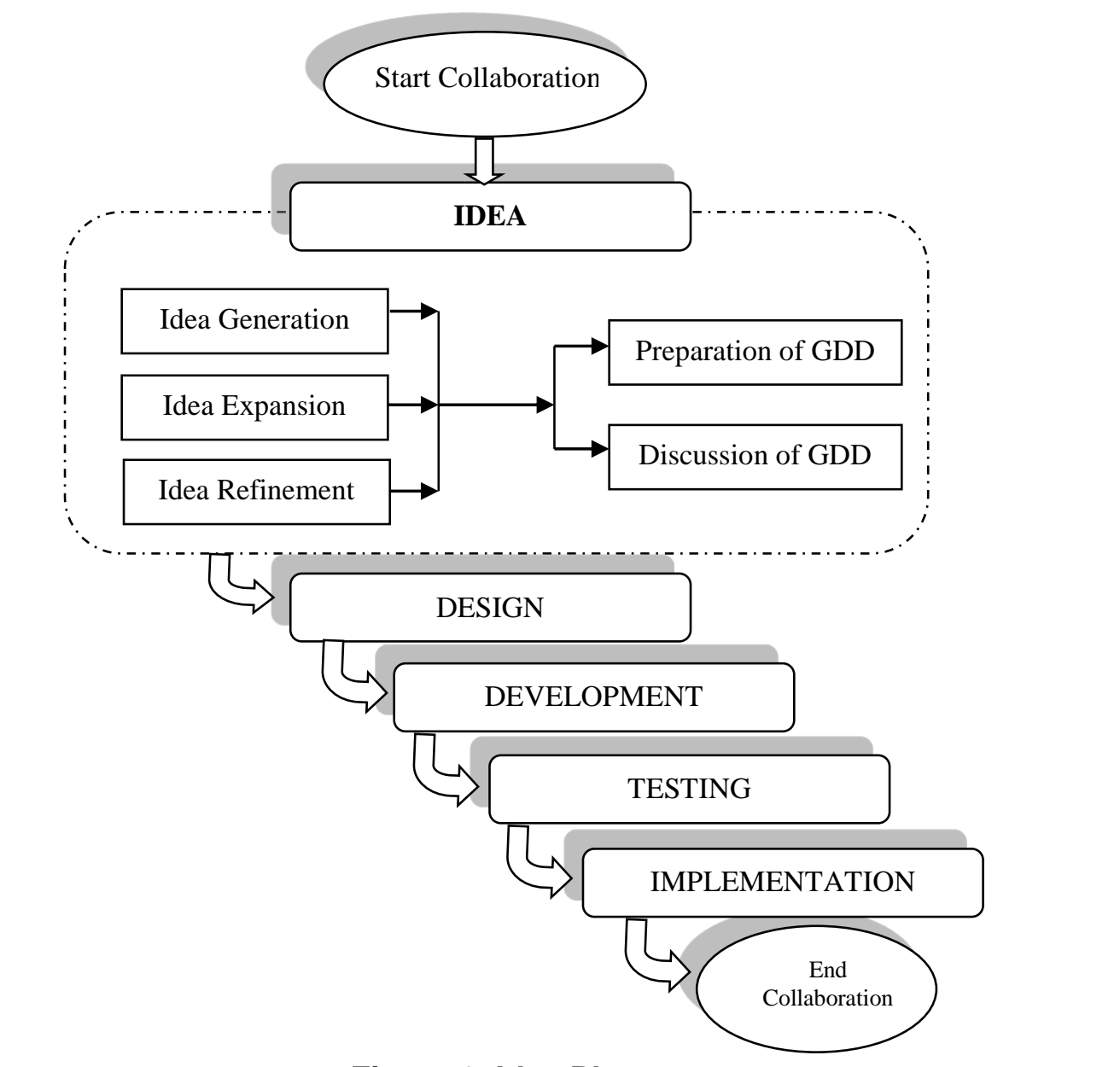

Figure 2. Idea Phase

The Design phase consists of two levels namely preparing the game design document (GDD) and discussing about the GDD (see Figure 3). In the preparation of GDD, all aspects related to game design and development tasks are included as game contents, including the instructional design, game design specifications, choice of programming language, research data collection and analysis, and logistics or feasibility of game production. The design of instruction covers matters related to learning syllabus, player analysis, instructional goals, learning outcomes, and planning for teaching and learning strategies. In terms of game design specifications, issues associated to game concept, genre, platform, core mechanics, flow 
charts, challenges and game goals, scoring rubrics, mode of play, types of characters, components of gameplay, function of user interface and narrative will be included in the GDD. In particular, constructive alignment was used to map the intended learning outcomes with in-game activities to ensure attainment in game playing means positive achievement in Mathematics [41]. As for the choice of programming language, the proposed platform, game engine and authoring tools will be determined and recorded in the GDD. If the practice of DGBL involves the conduct of empirical studies, the data collection and analysis will be noted in the GDD. The logistics or feasibility of production team would describe the expected level of educational background and technical expertise of required team members, along their assignments of tasks.

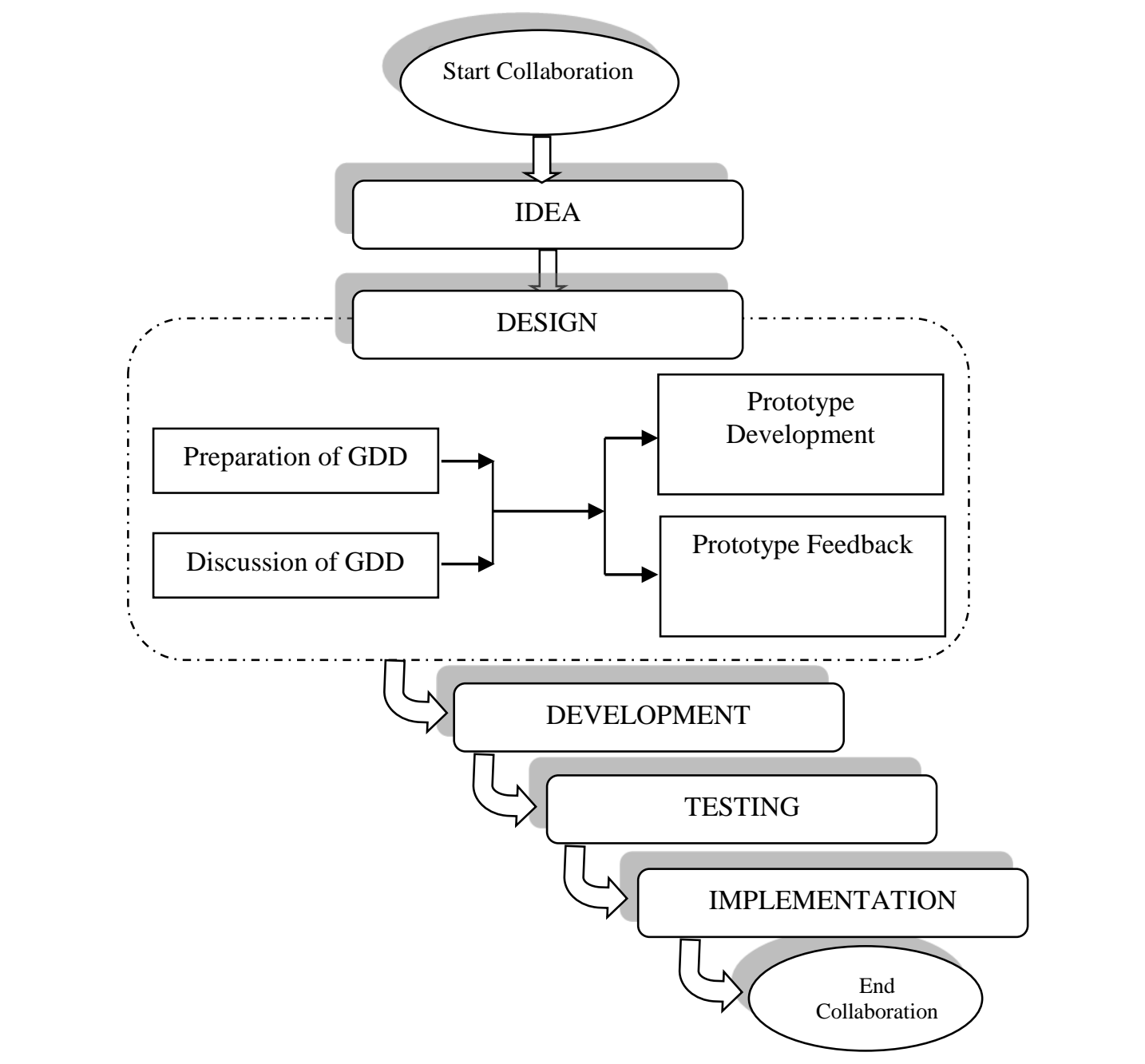

Figure 3. Design Phase

In the Development phase, technical experts are needed, including game programmers, game artists and music experts. Based on the specifications written in GDD and briefed by game designer, the game programmers will serve as an expert who turns rules set by human beings into computing codes, scripts and command which can be understood by computers. In particular, they will lead the production of a game prototype. In other words, game programmers realize who had been "designed" in actual game production settings. Working 
concurrent with the programmers, game artists provide design work needed in the games, including the characters in the game, the game environment, and navigational buttons. Music specialist will compose original music score and record sound effects for the game. Apart of prototype development, the Development phase also involves gathering feedback using the prototype (See Figure 4). Once the prototype was evaluated, feedback will be recorded. In practice, it is relatively easier to modify the game in the Design and the Development phases.

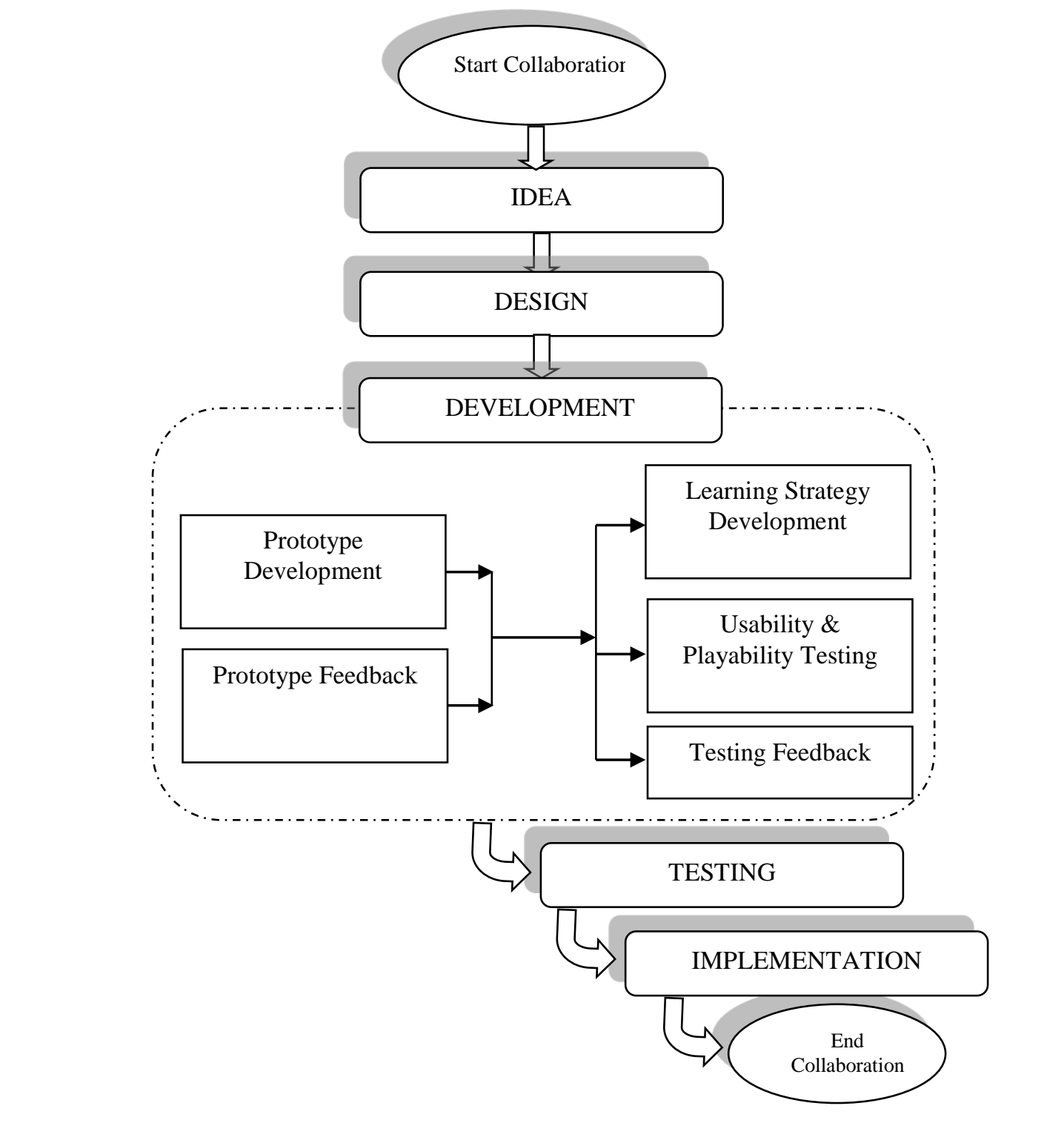

Figure 4. Development Phase

In the Testing phase, two types of tests will be conducted, i.e. the usability tests and the playability tests (see Figure 5). The usability testing can be sub-divided into five other tests: usefulness, efficiency, effectiveness, learnability and satisfaction. Usability testing is commonly conducted with a number of selected or voluntary students and at least one computing expert in the field of human computer interaction (HCI). Concurrent with the 
conduct of usability test, playability tests are carried out with some targeted students and GDEs in the game industry. Results collected from these tests will determine whether the game can and should be implemented in the classroom or not. Also, positive outcomes would be used to form the guiding principles that would be embedded in the development of learning strategies among the targeted players.

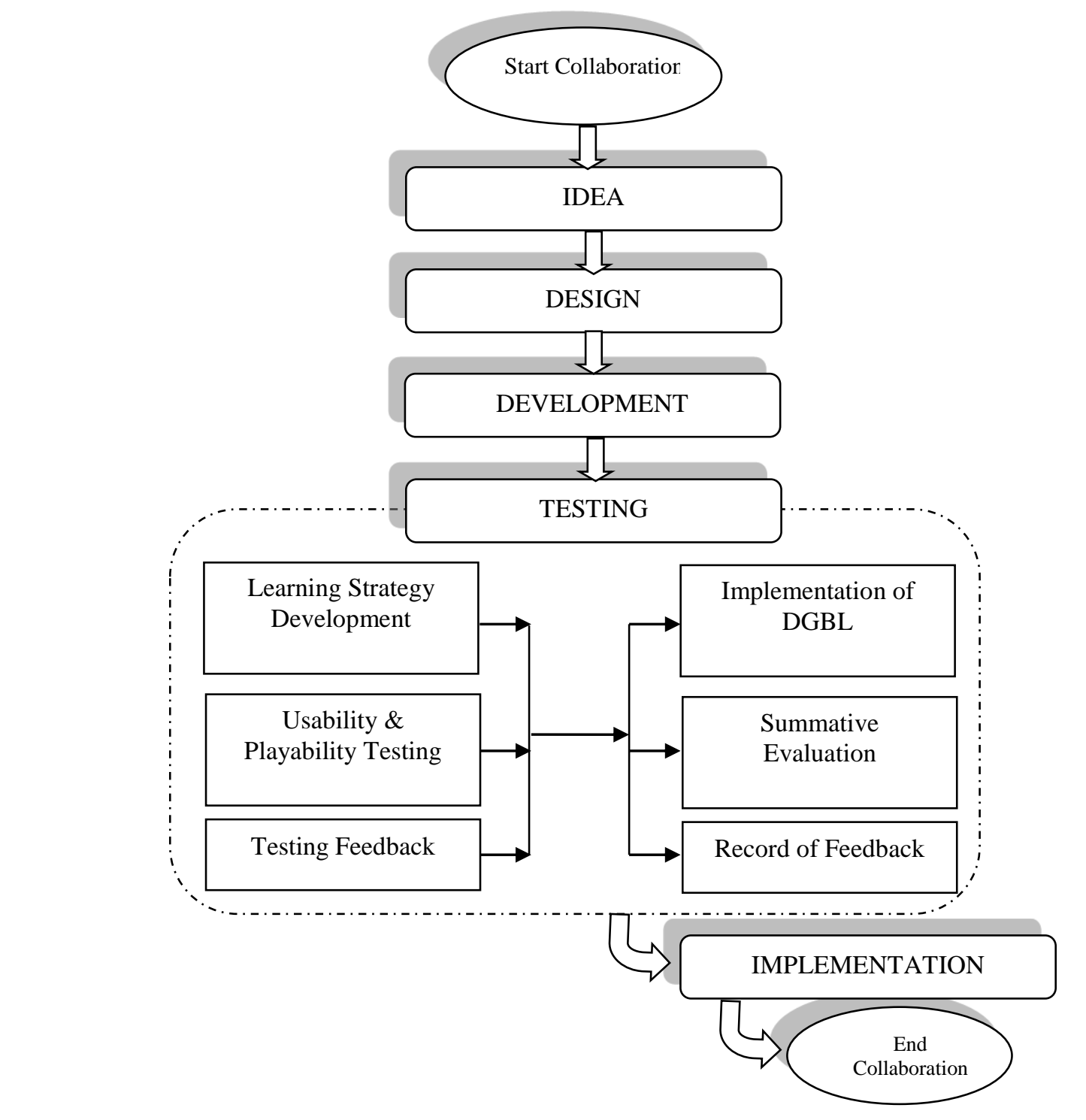

Figure 5. Testing Phase

In the Implementation phase, the game developed for use as a teaching aid in the classroom will be included in the DGBL practice (see Figure 6). The main target players are the remedial mathematics students. The implementation is cross-sectional, meaning that DGBL will be implemented within a predetermined timeframe, and evaluation tasks will be carried out. For instance, a quasi-experimental session could be conducted, involving pre-test and post-test. All activities will be recorded and then analyzed using statistical tools. The 
results of the analysis should be able to determine whether a specific use of digital game affect the performance of remedial students or not.

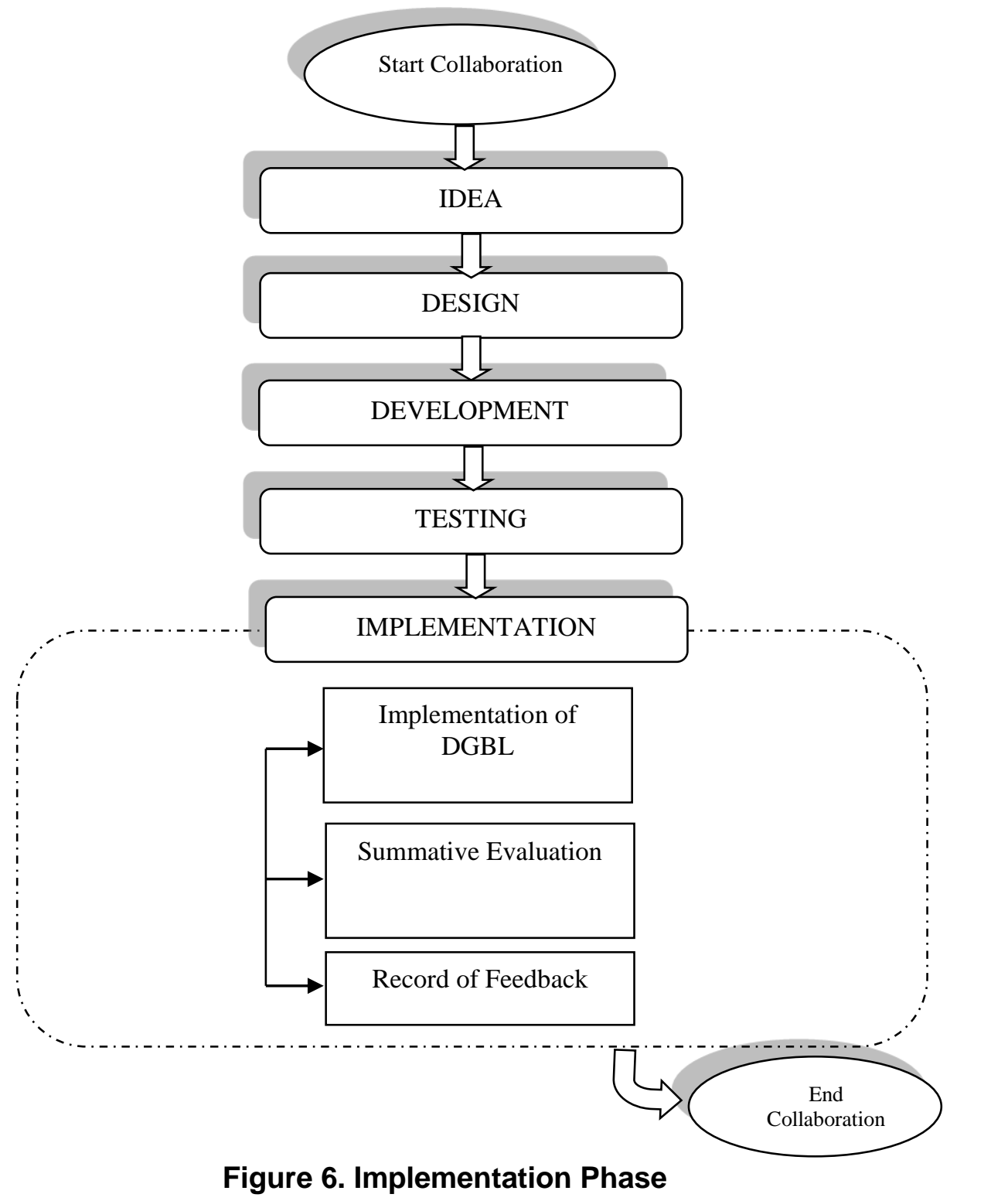

3.1.2. 1 Mini Ujian Matematik: An educational game titled 1 Minit Ujian Matematik has been designed and developed using the IDDTI model. The game was designed to teach students about the whole number (addition). The game is playable using tablet computer. As shown in Figure 7a, the game consists of two difficulty levels, i.e., easy (senang) and hard (sukar), in which they are presented in two similar layouts. The game menu indicates that there are two modes-the Quiz Mode (Mod Kuiz) and the Information Mode (Mod Maklumat), aiming to provide convenient access to essential learning contents to remedial students in the game (see Figure 7b). For instance, students are presented with 16 number boxes in the Easy Level (See Figure 7c); while there are 24 number boxes in the Hard Level (see Figure 7e). In either level, students must choose the correct number of boxes to perform addition calculation. The total 
must be same as the number displayed at the bottom left of the screen. Used box numbers will be diminished one-by-one (see Figure 7d and 7f), and students are given one minute to finish matching the sum of those numbers. Students who fail to finish within one minute will be given opportunity to repeat until they succeed.

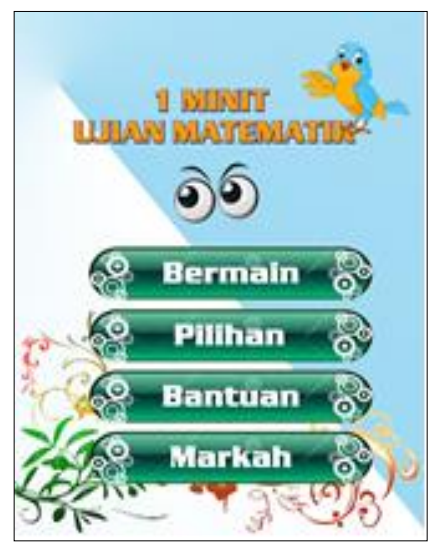

a. One Minute Math Test

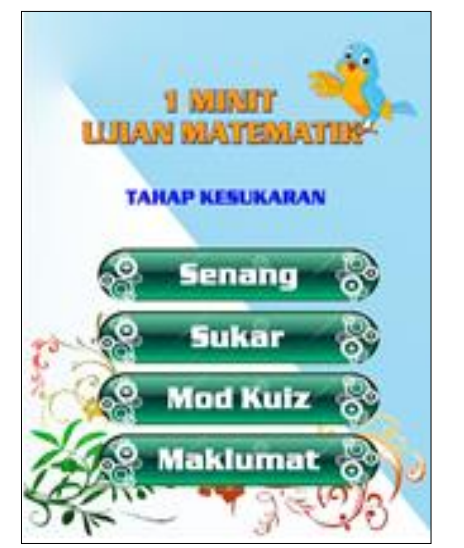

b. Level of Difficulty
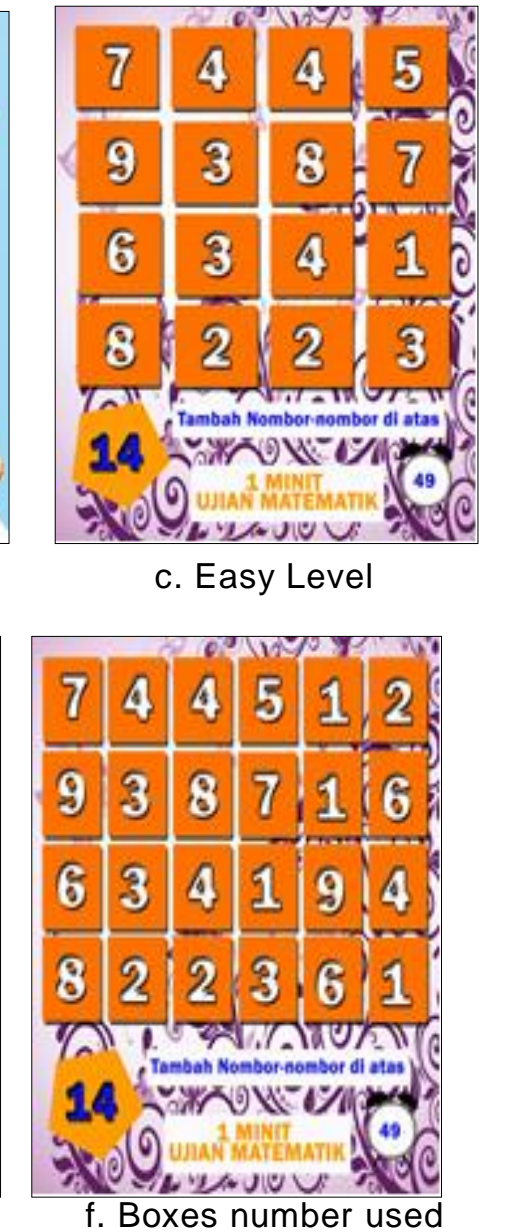

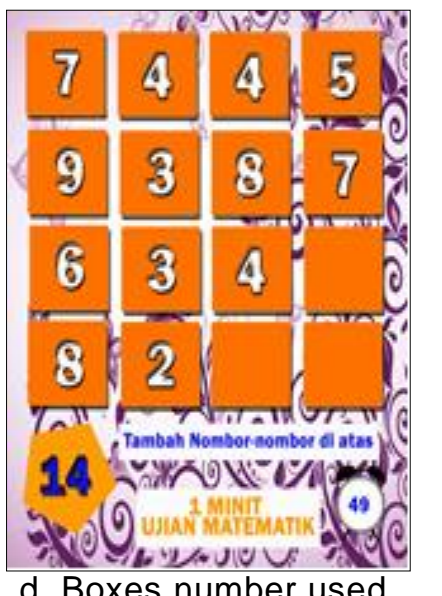

d. Boxes number used

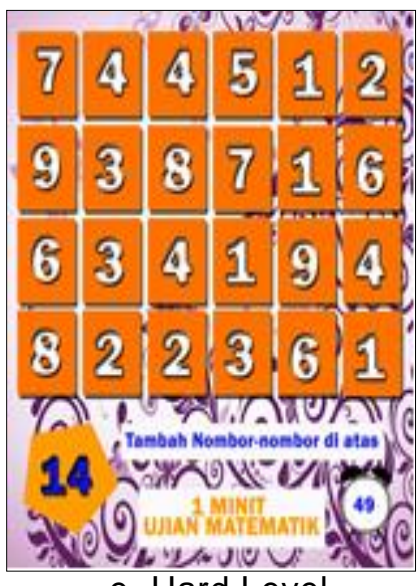

e. Hard Level

\section{Discussión}

\subsection{Question Associated to DGBL Practice}

The usefulness of the above mentioned IDDTI model and the practicality of the proposed DCBD practice in remedial mathematics lessons ought to be studied through empirical study. Hence the key research question: what is the impact of DGBL practice in the classroom on remedial mathematics student?

\subsection{Research Design}

The DGBL practice could be examined through a quasi-experimental study. This research design consists of pre and post-test [41-42]. Experimental methods are commonly used in the cases of empirical studies conducted in educational settings [42]. They are used to investigate 
the potential impact of educational innovations (often compared with other learning practices), in which observation of interactions between learners and the innovations takes place within the classroom environment, thus they are considered suitable for this kind of study.

Apart from examining the impact of the DGBL practice, this study also intends to identify suitable learning methods for remedial mathematics students in primary schools. These methods would be regarded as alternatives to the traditional teacher-centred learning methods. The sample involves 30 remedial students which would be gathered probably from more than one school as it is rare to have more than 30 remedial students in one school. Nevertheless, 30 samples is the minimum number of samples required for a reliable quasi-experiment[43]. The students will be divided into two equal groups: a treatment group and a control group. The treatment group would learn through DGBL method, while the control group would be taught by a school teacher. To ensure the rigour of this study, issues related to the variances, learning factor, teachers, the environment and the learning content are being taken care of [44].

Prior to the quasi-experiment, both the treatment and control group will be given a pre-test. The test contains questions picked from mathematical topics commonly covered in a remedial lesson. After recording the score of each participant the treatment group will be directed to learn using the 1 Minit Ujian Matematik game while the control group will be taught by a teacher, using flash card and lecture. At the end of the learning sessions, the participants will be instructed to sit for the post-test.

The data will be collected based on test score, in the pre and post- tests. The scores will be analysed through t-test using the Statistical Package for the Social Sciences (SPSS) to identify whether there is any significant effectiveness when DGBL approach is used in remedial mathematics lessons. T-test is appropriate for analysing data between two interval or ratio data. In particular, one-way ANOVA will be ased to compare the mean or the relationship between the dependent variables and independent variables in this study.

\section{Conclusion}

As shown in DGBL literatare, many researchers used digital games as a medium of learning and yielded positive results on students' learning motivation and achievement. However, the lack of god quality games, specifically for remedial students in mathematics has retarded the potential of DGBL.

A model for DGBD model, named as IDDTI model, has been created to fill in the gap, in which the model synergizes the expertise from SMEs in the academia and GDE from the game industry to design and develop games for use in remedial educational settings. Aremedial mathematics game, titled 1 Minit Ujian Matematik was created based on the IDDT nodel, justifying the feasibility of the model.

Nonetheless, the IDDTI model should be tested to identify the impact of DGBL practice in theclassroom on remedial mathematics students, which in turn recognizing suitable learning methods for the students in primary schools.

\section{Acknowledgement}

This research study is sponsored by the Malaysian Ministry of Education under the Hadiah Latihan Persekutuan (HLP) scheme. 


\section{References}

[1] A. M. Sedaghat, S. M. Mintz and G. M. Wright, "Using Video-Based Instruction To Integrate Ethics Into The Curriculum", Am. J. Bus. Educ., vol. 4, no. 9, (2011), pp. 57-76.

[2] G.-J. Hwang and P.-H. Wu, "Advancements and trends in digital game-based learning research: a review of publications in selected journals from 2001 to 2010", Br. J. Educ. Technol., vol. 43, no. 1, (2012), pp. E6E10.

[3] C. Lin and E. Z. Liu, "A Comparison between Drill-Based and Game-Based Typing Software", in Transactions on Edutainment III, Lecture Notes in Computer Science, vol. 5940, (2009), pp. 48-58.

[4] E. Z. F. Liu, "Avoiding Internet addiction when integrating digital games into teaching", Soc. Behav. Personal. an Int. J., vol. 39, no. 10, (2011), pp. 1325-1335.

[5] M. Prensky, "Digital game-based learning," Comput. Entertain", vol. 1, no. 1, (2003), p. 21.

[6] Y.-H. Chen, C.-P. Lin, C.-K. Loi, Y. Shao and T.-W. Chan, "A Collaborative Cross Number Puzzle Game To Enhance Elementary Students' Arithmetic Skills", Turkish Online J. Educ. Technol., vol. 11, no. 2, (2012), pp. 1-15.

[7] M. Papastergiou, "Digital Game-Based Learning in high school Computer Science education. Impact on educational effectiveness and student motivation", Comput. Educ., vol. 52, no. 1, (2009), p

[8] D. K. Swearingen, "Effect Of Digital Game Based Learning On Ninth Grade Students Mathematics Achievement", Oklahoma University, (2011).

[9] M. Karafili and A. Stana, "The Learning of Mathematics Supported by GBL - A Noyelty for Albanian Preschool System", J. Educ. Soc. Res., vol. 2, (2012), pp. 297-306

[10] L. E. Yee, W. A. Wan Zah, M. Rosnaini and B. Roselan, "Form one students' engagement with computer games and its effect on their academic achievement in a Malays an secondary school”, Comput. Educ., vol. 53, no. 4, (2009), pp. 1082-1091.

[11] R. Garris, R. Ahlers and J. E. Driskell, "Games, Motivation, and Learning: A Research and Practice Model", Simul. Gaming, vol. 33, no. 4, (2002), pp. 441-467,

[12] I. Iacovides, J. Aczel, E. Scanlon, J. Taylor and W. Woods, "Motivation, Engagement and Learning through Digital Games", Int. J. Virtual Pers. Learn. Environ., vol. 2, no. 2 (2011), pp. 1-16.

[13] H. Panoutsopoulos and D. G. Sampson, "A Study on Exploiting Commercial Digital Games into School Context", Educ. Technol. Soc., vol. 15, no, (2012), pp. 15-27.

[14] M. Kebritch and A. Hirumi, "Examining the pedagogica foundations of modern educational computer games", Comput. Educ., vol. 51, no. 4, (2008), pp. $1729-1743$.

[15] Kementerian Pelajaran Malaysia, Pelaksanaan Program Pemulihan Khas ( Edisi Percubaan )", Jabatan Pendidikan Khas, (2008), p. 3

[16] J.-J. Lo, H.-M. Wang and S.-W Yeh, "Effects of confidence scores and remedial instruction on prepositions learning in adaptive hypermedia", Compu Educ., vol. 42, no. 1, (2004), pp. 45-63.

[17] Y.-F. Yang, "Developing a reciprocal teaching/learning system for college remedial reading instruction", Comput. Educ., v61. 55, no. 3, (2010) pp. 1193-1201.

[18] W. H. Tan S. Johnston-Wilden and S. Neill, "Examining the potential of game-based learning through the eyes of maths trainee teachers Proc. Br. Soc. Res. into Learn. Math., vol. 28, no. 3, (2008), pp. 120-124.

[19] Y. Chiang, S. S. J. Lin, C-Y. Cheng and E. Z.-F. Liu, "Exploring Online Game Players' Flow Experiences And Positive", Turkisb Onlme J. Educ. Technol., vol. 10, no. 1, (2011), pp. 106-114.

[20]S. Ko, "An Empirical Analysis of Children's Thinking and Learning in a Computer Game Context", Educ. Psychol., vol. 22 no. 2, (2002), pp. 219-233.

[21] J. P. Gee, "Good videogames and good learning: Collected essays on video games", Peter Lang Publishing, (2007), p 13.

[22] J. A. Betz Computer Games: Increase Learning in an Interactive Multidisciplinary Environment”, J. Educ. Technol. Syst., vol. 24, no. 2, (1995), pp. 195-205.

[23] R. Moreno, "Who Learns Best with Multiple Representations? Cognitive Theory Predictions onIndividual Differences in Multimedia Learning", in World Conference on Educational Multimedia, Hypermedia \& Telecommunications., (2002), p. 7.

[24] J.Piaget, "Play, Dreams and Imitation in Childhood", 2nd ed. William Heinemann, (1951), p. 296.

[25] K. R. Ota and G. J. DuPaul, "Task Engagement and Mathematics Performance in Children with AttentionDeficit Hyperactivity Disorder: Effects of Supplemental Computer Instruction”, Sch. Psychol. Q., vol. 17, no. 3, (2002), pp. 242-257.

[26] F. Ke, "Classroom Goal Structures for Educational Math Game Application", in ICLS '06 Proceedings of the 7th international conference on Learning sciences, (2006), pp. 314-320.

[27] Y. L. Lee, "A Maths Game Model for Learning Fractions”, Int. J. Learn., vol. 14, no. 12, (2008), pp. 225234. 
[28] Z. Chen, C. C. Y. Liao, H. N. H. Cheng, C. Y. C. Yeh and T. Chan, "Influence of Game Quests on Pupils ' Enjoyment and Goal-pursuing in Math Learnin”, Educ. Technol. Soc., vol. 15, (2012), pp. 317-327.

[29] M. Ntourlia, D. Gouscos and M. Meimaris, "TuxMath : Is it Possible for a Game to Enhance Multiplication Skills ?", in Proceedings of the 4th European Conference on Games Based Learning, (2010), pp. 280-291.

[30] M. Vandermaas-peeler, L. Ferretti and S. Loving, "Playing The Ladybug Game: parent guidance of young children's numeracy activities, Early Child Development and Care”, Early Child Dev. Care, vol. 182, no. 10, (2012), pp. 1289-1307.

[31] I. Gallegos and A. Flores, "Using Student-Made Games to Learn Mathematics", Primus Probl. Resour. Issues Math. Undergrad. Stud., vol. 20, no. 5, (2010), pp. 405-417.

[32] C. Hung, I. Huang and G. Hwang, "Effects of digital game-based learning on students' self- efficacy, motivation, anxiety, and achievements in learning mathematics", J. Comput. Educ., (2014).

[33] OECD, "Executive Summary of The Programme for International Student Assessment (PISA): Science Competencies for Tomorrow's World", (2006).

[34] P. Felicia, "Digital games Teacher Handbook", brussels belgium: european shoolnet, (2009), p. 46.

[35] Kementerian Pelajaran Malaysia, "Laporan jawatankuasa kabinet mengkaji pelaksanaan dasar pelajaran", (1979).

[36] B. Mohd Razali, "Satu Kajian Mengenai Pelaksanaan Aktiviti Pemulihan Matematik Di BilikDarjah Bagi SK Jelai 1 (FELDA) Gemas Negeri Sembilan”, Istitut Perguruan Sultan Idris, (1989).

[37] Kementerian Pendidikan Malaysia, "Manual Am - NKRA : Instrumen Satingan Numerási”, (2013), p. 15.

[38] B. D. Herbert, "Production of large computer programs", IEEE Annats af the History of Computing, vol. 5, no.4, (1983), pp. 350-361.

[39] W.H. Tan, S. Neill and S. Johnston-Wilder, "Why game-based tearning did not achieve what it could achieve: challenges and success factors", in Educational Technology Use and Design for Improved Learning Opportunities. Hershey: IGI Global, (2014), pp. 269-285.

[40] P. Hekkert, "Design aesthetics: principles of pleasure in design", Psychology Science, vol. 48, no. 2, (2006), pp. 157-172.

[41] J. B. Biggs, "Teaching for quality learning ât university", 2nd ed. Buckingham: Open University Press, (2003).

[42] W. Wiersme, "Research Methods In Education: An Introduction", 4th ed. Boston: Allyn and Bacon, (1986), p. 466.

[43] L. Cohen, L. Manion and K. Morrison, "Research Methods in Education", (2007), p. 638.

[44] J. R. Fraenkel and N. E. Wallen, "How To Desfgn Ang Evaluate Research In Education", 6th ed. Boston: McGraw-Hill, (2006), p. 497.

[45] S. Robiah and M. Nor Sakinah, "ICT dalam Pendidikan: Prospek dan Cabaran dalam Pembaharuan Pedagogi", J. Pendidik., vol.32)(2007), pp. 139-152.

[46] Purdue University, "Game Development Process", [Online]. Available: http://www.egames.tech.purdue.edu/GameDevProcess.asp., (2007).
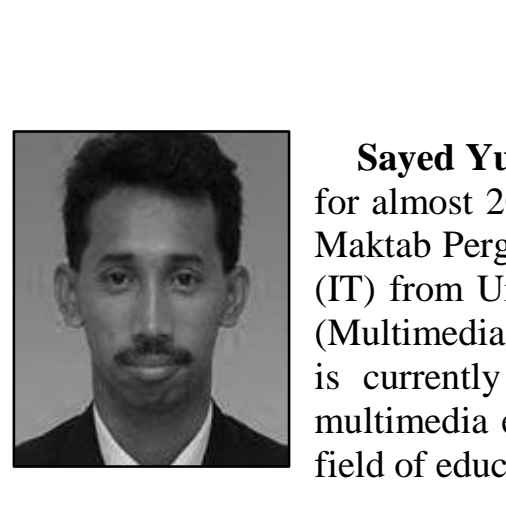

Oayed $Y$

Sayed Yusoff Syed Hussain is a school teacher and has been teaching for almost 20 years in Malaysia. He received a teaching certificate from Máktab Perguruan Sultan Abdul Halim in 1994, a Bachelor of Education (IT) from Universiti Utara Malaysia in 2005 and a Master of Education (Multimedia) from Universiti Pendidikan Sultan Idris (UPSI) in 2011. He is currently pursuing a doctorate degree with UPSI in the area of multimedia education, in which he develops his research interests in the field of education, multimedia and computing.

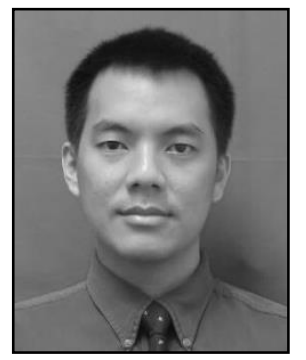

Wee Hoe Tan is the Deputy Director of Education Research Laboratory, Sultan Idris Education University. After the completion of a doctorate degree in game-based learning from University of Warwick in 2011, he began working between the creative industry and the academia, facilitating university-industry collaboration in Malaysia, UK and US. He 


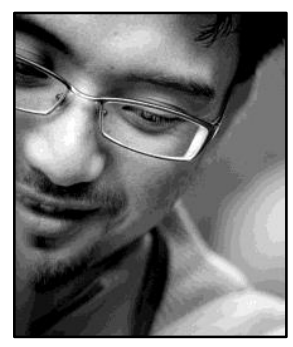

research interests spread across various fields in creative multimedia and inventive problem solving.

Dr. Muhammad Zaffwan Idris is a senior lecturer at Universiti Pendidikan Sultan Idris, a Malaysian public university located in Tanjong Malim. He received his Doctoral certificate from Swinburne University of Technology, Melbourne in 2011. His thesis entitled 'Branding in Higher Education: Testing the effectiveness of corporate visual identity'. Since then, his research interest has expended into other related areas within the scope of creative industry such as animation, games and integrated media.

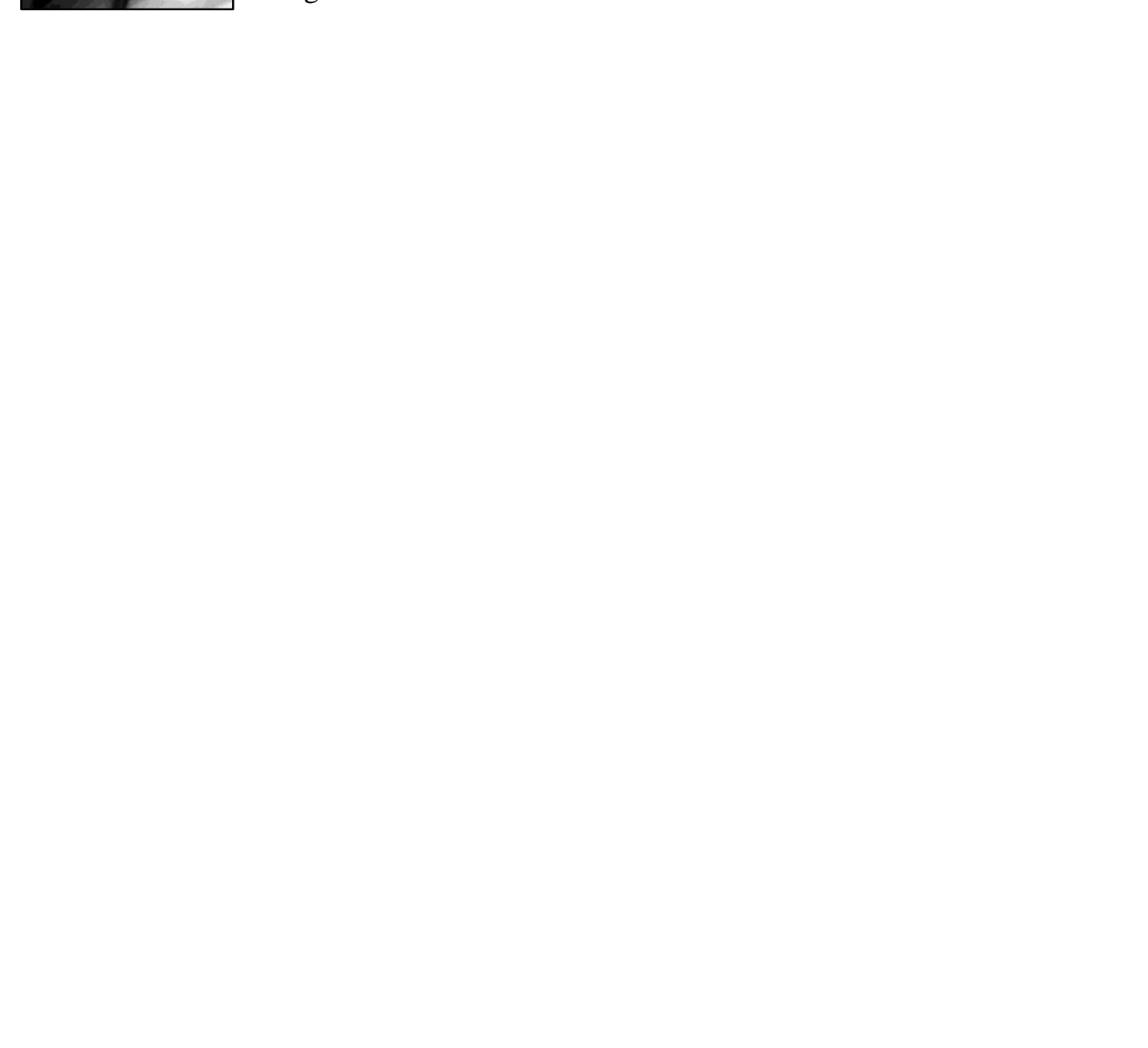


International Journal of Multimedia and Ubiquitous Engineering Vol. 9, No. 11 (2014)

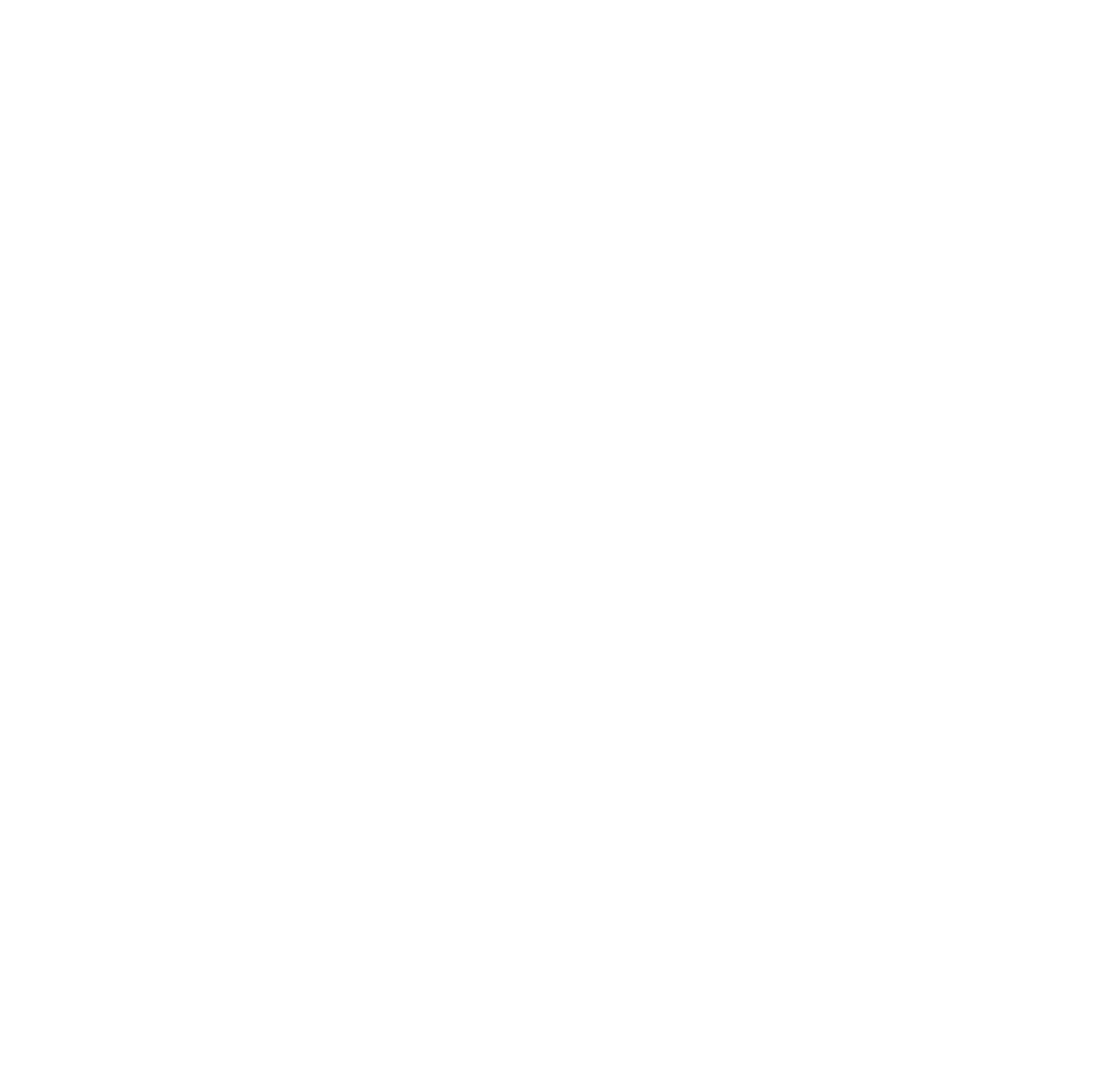

